Отримано: 10 березня 2018 р.

Прорецензовано: 15 березня 2018 р.

Прийнято до друку: 19 березня 2018 р.

e-mail: galmikhnenko@gmail.com

DOI: $10.25264 / 2519-2558-2018-1(69) / 2-32-34$
Mikhnenko Galyna. Realization of blended learning ideas in teaching english for specific purposes. Наукові записки Начіонального університету «Острозька академія»: серія «Філологія». Острог : Вид-во НаУОА, 2018. Вип. 1(69), ч. 2, березень. С. 32-34.

\author{
Galyna Mikhnenko, \\ National Technical University of Ukraine "Igor Sikorsky Kyiv Polytechnic Institute”, Kyiv
}

УДК 378.147

\title{
REALIZATION OF BLENDED LEARNING IDEAS IN TEACHING ENGLISH FOR SPECIFIC PURPOSES
}

Intercultural integration and changing settings in the modern world of professionals require implementing the new models of teaching foreign languages for specific purposes that involve extensive use of information and communication technologies and blended learning methods. The article is devoted to the use of e-learning distance courses in a technical university educational environment as a method of blended learning. The reasons for using blended learning technologies are given. The results of survey on general orientation of the students' motivation to study are presented. The e-learning distance course on English for Specific Purposes has been implemented, and its content and students' feedback are considered. It is concluded that the realization of the ideas of blended learning in teaching English for Specific Purposes through e-learning distance courses should be methodologically justified, that is balanced with face-to-face instruction. In such a way this method can become a key link between current technologies, professional knowledge and effective learning conditions.

Key words: blended learning, educational environment, information and communication technologies, e-learning distance course, English for Specific Purposes.

Міхненко Галина Едуардівна,

Національний технічний університет Украйни «Київський політехнічний інститут імені Ігоря Сікорського», м. Київ

\section{РЕАЛІЗАЦІЯ ІДЕЙ ЗМІШАНОГО НАВЧАННЯ У НАВЧАННІ АНГЛІЙСЬКОЇ МОВИ ДЛЯ СПЕЦАЛЬНИХ ЦІЛЕЙ}

Міжкультурна інтеграція та швидкі зміни у сучасному світі потребують впровадження нових моделей навчання іноземних мов для спеціальних цілей, щзо передбачає широке використання інформаційно-комунікаційних технологій та методів змішаного навчання. Стаття присвячена використанню мультимедійних дистаниійних курсів в освітньому середовищі технічного університету як методу змішаного навчання. Розглядаються переваги змішаного навчання та відгуки студентів щзодо їхньої роботи над дистаниійним курсом, проведеної у межах часу, відведеного для індивідуальної роботи студентів. Зроблено висновок, ио реалізаиія ідей змішаного навчання у навчанні іноземної мови повинна бути методологічно обтрунтованою та враховувати особливості навчальної дисичиліни.

Ключові слова: змішане навчання, освітнє середовище, інформаційно-комунікаційні технологї, мультимедійний дистанційний курс, англійська мова для спеціальних изілей.

Михненко Галина Эдуардовна,

Национальный технический университет Украины «Киевский политехнический институт имени Игоря Сикорского», г. Киев

\section{РЕАЛИЗАЦИЯ ИДЕЙ СМЕШАННОГО ОБУЧЕНИЯ В ПРЕПОДАВАНИИ АНГЛИЙСКОГО ЯЗЫКА ДЛЯ СПЕЦИАЛЬНЫХ ЦЕЛЕЙ}

\begin{abstract}
Межкультурная интеграция и быстрые изменения в современном мире требуют внедрения новых моделей обучения иностранным языкам для специальных иелей, что предполагает иирокое использование информачионно-коммуникаиионных технологий и методов смешанного обучения. Статья посвящена использованию мультимедийньх дистанционньх курсов в образовательной среде технического университета как метода смешанного обучения. Рассматриваются преимушества смешанного обучения и отзывы студентов об их работе над дистанционным курсом, проведенной в рамках времени, отведенного для индивидуальной работы студентов. Сделан вывод, что реализачия идей смешанного обучения в обучении иностранному языку должна быть методологически обоснованной и учитывать особенности учебной дисииплины.
\end{abstract}

Ключевые слова: смешанное обучение, образовательная среда, информационно-коммуникационные технологии, мультимедийный дистанционный курс, английский язык для специиальных ияелей.

In the modern world of intercultural integration and changing settings, foreign language acquisition proves to be the necessity for a highly qualified specialist in any sphere. It is a fact and must-have. Nevertheless, the foreign language teaching process itself, especially teaching English for Specific Purposes (ESP), although characterized by positive changes and wide use of interactive methods, still requires creating and implementing the new models of teaching ESP that involve the developments in modern education such as: interdisciplinary integration, variability, use of information and communication technologies (ICT), etc.

Foreign language teaching at our universities remains conservative, giving too much focus on learning about the language rather than learning through or with language [6], whereas it must also fulfil the task of developing key personal skills and competences of a professional.

According to the survey conducted at Igor Sikorsky Kyiv Polytechnic Institute, 78\% of students hope that as a result of the professional training they will realize their studying dreams and expectations. At the same time, only $60 \%$ of the respondents believe that the educational environment of their university fully promotes intellectual development, and up to $46 \%$ of them think that the main thing is only to get a diploma and Bachelor's /Master's degree. The students are not always satisfied with the existing traditional system of both general professional training and the teaching of humanities, pointing out insufficiency in the number of problem solving tasks and lack of using ICT in studying process [4]. 
The analysis of research in pedagogy and psychology (V. Krasilnikova [1], K. Krechetnikov [2], G. Selevko [5], etc.) allowed us to determine such advantages of using ICT in the educational environment of a technical university:

- possibility of implementing an activity-based approach and learner-centered approach while maintaining holistic learning;

- possibility of building an open system of education, which provides every student with his/her own trajectory of studying and self-learning;

- creation of an effective system of information and teaching materials management;

- increased motivation of students;

- availability of ICT at any time.

Among the popular ways of using ICTs in an educational environment are as follows: electronic textbooks, encyclopedias; roleplays and intellectual games by using artificial intelligence; distance learning; conducting educational teleconferences, webinars; use of controlling test programs and presentations, etc.

ICTs are a powerful factor in motivating learning and intellectual development of future engineers. On the one hand, they help to conceive the importance of professional tasks, increase the relevance and novelty of learning content as electronic training materials can be continuously updated. On the other hand, ICTs meet intellectual interests of young people, who prefer multitasking on mobile devices: communicating with friends, searching for information, listening to music, etc.

One of the promising areas of using ICT in education is so called "blended learning". The meaning of this concept has changed over time. N. Friesen [7] proposes the following definition: "Blended learning" designates the range of possibilities presented by combining Internet and digital media with established classroom forms that require the physical co presence of teacher and students".

Thus, blended learning combines conventional and modern technologies: face-to-face instruction and technology-mediated instruction. The model does not consider radical rejection of traditional education, since full-time education provides the development of important linguistic and socio-cultural skills.

Hauk and Stickler [8] believe that blended learning can be a solution to learning problems. Osguthorpe and Graham [9] distinguish six reasons for using blended learning models in education: improved pedagogical approaches, access to teaching materials, social interaction, student's personal choice and self-control; low cost; facilitated revision of the learning material.

ICT in the classroom is not a memory stick with a presentation, but modern educational online services, training platforms, virtual laboratories, cloud multimedia applications, chat rooms, educational projects, etc. Thus, the main task for the faculty is the development of educational and methodological support for individual work of students.

Since professional training stipulates the readiness of a future engineer to quickly find and process as well as effectively apply information to fulfil both reproductive and creative tasks, the content of the training material must meet the requirements of speed and unpredictability during the performance of these tasks. Also the effective tasks are those with different levels of complexity, or competitive nature as well as time limitation on performance. It goes without saying, it is easier to fulfil these requirements by introducing e-learning distance courses in the educational environment of a technical university and, in this way, realize some ideas of blended learning in teaching ESP in practice.

The aim of this article is to analyse the use of e-learning distance course in teaching English for Specific Purposes at the technical university as a method of blended learning.

E-learning distance course allows differentiating the learning process, monitoring a student with feedback, and increasing students' interest in learning by using game tasks.

One of the most popular e-learning platforms in the world is Moodle (Modular Object-Oriented Dynamic Learning Environment) developed in 2002 (https://moodle.org/). The main characteristics that make this system a leading e-learning platform are as follows:

- supporting more than 40 languages of the world and various databases (PostgreSQL, MSSQL, MySQL, Oracle, text file);

- having an easy to understand and use interface;

- expanded functionality and possibility to present and update educational materials in various formats;

- allowing the control of the obtained knowledge in automatic or remote manual modes, updating of a student's learning individual plan according to his/her results;

- conducting the assessment of students' knowledge on the basis of testing methods (matching tasks, multiple choice, etc.).

In addition to the possibility to use multimedia and the tools such as wiki, blog, forum, glossary, questionnaire, etc., the teacher can change the time for performing tasks and the number of attempts, as well as vary assignments and give a student the right to choose them. You can also organize online lectures, webinars and seminars. By means of the function of personal comments it is possible to discuss the problems personally with the teacher.

We developed and introduced into practice the e-learning distance course called "English for Future Engineers" for the third and fourth year students of technical departments at Igor Sikorsky Kyiv Polytechnic Institute [3].

Our ESP e-learning distance course has been used within the time allocated for the individual work of students (self-study). It consists of five modules and a final test. Each module includes listening and reading comprehension tasks, glossary, practice in specialty vocabulary and grammar structures used in a professional setting as well as the tasks to write business correspondence (CVs, job applications, etc.).

The professionally-oriented topics about the specifics of engineering work, recruitment and selection, motivation to perform work, professional development and safety rules in the workplace are discussed in the context of the activities of the UK energy companies. This contributes to the formation of sociocultural competence of the students and motivation for learning ESP. The format of an e-learning course allows the students to get acquainted with some knowledge in psychology, personal development and requirements to a professional.

The final test aims at checking students' performance. Reference materials are also offered; they include practical recommendations on writing a resume, letters of application and job interview tips.

The students performed the tasks of the course in two modes: the initial mode when they could to see the keys to the tasks for self-check and the test mode. After completing the tasks, the students used the forum and questionnaire to express their impressions 
about the course, mentioned interesting and useful activities, gave recommendations to the students who would perform the tasks of this course in future.

It is important to note that students highly appreciated the possibility of self-control and self-correction of their work while doing in the training mode as well as the implementation of an individual approach. They pointed out that limiting the number of attempts and time greatly contributed to the mobilization of their intellectual resources and interest in learning. The students compared the learning process with a game, which is a fundamental difference between an e-learning course and the traditional set of exercises in ESP teaching practice. Some results of the questionnaire are given in Table 1.

The attitude of students towards the tasks of the e-learning distance course "English for Future Engineers"

Table 1

\begin{tabular}{|c|l|c|}
\hline No & \multicolumn{1}{|c|}{ Questions } & more“"yes" than "no" \\
\hline & I am quite satisfied with my progress in processing the material. & $82,61 \%$ \\
\hline & The course tasks are interesting and informative. & $83,61 \%$ \\
\hline & $\begin{array}{l}\text { I liked the course on the Moodle platform as I was able to independently plan my work at } \\
\text { the time frame set by my teacher. }\end{array}$ & $78,26 \%$ \\
\hline & As a result of performing the tasks, my professional vocabulary has expanded greatly. & $78,26 \%$ \\
\hline & I spent less time every other time when doing the tasks from the following section. & $52,18 \%$ \\
\hline & My interest in learning ESP has increased after doing this course. & $69,57 \%$ \\
\hline $\begin{array}{l}\text { The use of e-learning distance courses can contribute to the creation of an effective } \\
\text { learning environment. }\end{array}$ & $73,91 \%$ \\
\hline
\end{tabular}

Here are some advantages of the course in the students' words: "close connection between the content of the course and special disciplines", "a great number of interesting topics and ESP vocabulary", "instant check of tasks in the training mode", "possibility to perform tasks in any place at any time", "this course adds zest to learning". Most students expressed the idea that the use of elearning courses in professional training of future engineers could contribute to the creation of the effective learning environment of a technical university.

Conclusion. Considering all the advantages of applying ESP e-learning distance courses in tertiary education, we should admit the importance of face-to-face ESP teaching in classrooms and consider finding the right balance of time allocated for both faceto-face and technology-mediated instruction to be a crucial principle in blended learning. The choice of teaching methods should always be pedagogically and economically justified; in our case, the peculiarities of ESP teaching should be considered. In addition, to implement educational potential of electronic resources, it is necessary to apply them systematically.

At present, the use of ICTs and blended learning technologies in teaching ESP is a necessity that results from both scientific and technological progress and needs of intercultural society. So, we recommend: 1) to create an educational environment that encourages students to take part in intellectual activities with active usage of ICTs and Internet resources; 2) to improve syllabuses by means of using ICTs in a system way by using e-learning distance courses, and thus realizing the ideas of "blended learning"; 3) to organize the learning process on the basis of problem solving activities to enrich the cognitive experience of students and take this into account when creating training materials of various levels.

\section{References:}

1. Красильникова В. А. Информационные и коммуникационные технологии в образовании : учеб. пособ. / В. А. Красильникова. - М. : ООО «Дом педагогики», 2006. - 231 с.

2. Кречетников К. Г. Проектирование креативной образовательной среды на основе информационных технологий в вузе : монография / К. Г. Кречетников. - М. : Госкоорцентр, 2002. - 296 с.

3. Міхненко Г. Е. Мультимедійний дистанційний курс «Англійська мова для майбутніх інженерів» для студентів 3-4 курсів технічних факультетів НТУУ «КПІ» : навч.-метод. праця (Сертифікат № 4248 УІІТО НТУУ «КПІ») / Г. Е. Міхненко. - 2014. - Режим доступу : http://moodle.ipo.kpi.ua/moodle/course/view/php?id=635.

4. Міхненко Г. Е. Формування інтелектуальної мобільності майбутніх інженерів в умовах освітнього технічного університету : автореф. дис. На здобуття наук. ступеня канд. пед. наук : спец. 13.00.04 «Теорія і методика професійної освіти» / Міхненко Галина Едуардівна; Національний авіаційний університет. - К., 2016. - 20 с.

5. Селевко Г. К. Энциклопедия образовательных технологий. В 2х т. / Г. К. Селевко. - М. : Народное образование, 2006. - Т. 1. $-845 \mathrm{c}$.

6. Cammarata L., Tedick, D. J. \& Osborn, T. A. Content-Based Instruction and Curricular Reforms: Issues and Goals. / L. Cammarata (Ed.) // Content-based foreign language teaching: Curriculum and pedagogy for developing advanced thinking and literacy skills. - NY and London: Routledge, 2016. - pp. 1-22.

7. Friesen N. Report: Defining Blended Learning [Electronic resource] - 2012. - Retrieved from : <http://learningspaces.org/papers/ Defining Blended Learning NF.pdf $>$

8. Hauck M., Stickler U. What does it take to teach online? / Mirijam Hauck, Ursula Stickler // CALICO Journal, Special Issue : What does it take to teach online? Towards a Pedagogy for Online Language Teaching and Learning. - Vol. 23. - No. 3. - Equinox Publishing Ltd., 2006. - pp. 463-475.

9. Osguthorpe R.T., Graham C.R. Blended learning systems: Definitions and directions. // Quarterly Review of Distance Learning. -4 (3). -2003 . - pp. 227-234. 